\title{
Recent challenges and advances in genetically-engineered cell therapy
}

\author{
Seok-Beom Yong ${ }^{1,3} \cdot$ Jee Young Chung ${ }^{1,3} \cdot$ Yoonsung Song ${ }^{1,3} \cdot$ Yong-Hee Kim $^{1,2,3}$
}

Received: 7 November 2017 / Accepted: 14 December 2017 / Published online: 28 December 2017

(c) The Author(s) 2017, corrected publication October 2018

\begin{abstract}
Cells naturally sense and actively response to their environment. Cell-therapy has long been studied and shown therapeutic effects in various diseases. However, several hurdles should be overcome to improve cell-based therapy. Gene deliverymediated cellular modification has shown improvement of cell function by obstacle gene silencing and therapeutic gene expression. Especially, CRISPR/Cas9-mediated genome editing is a very promising method for gene modification. In this review, we describe the recent advances in genetic modification for cell therapy. Stem cells are still promising source of cell therapy due to their self-renewal character and differentiation potential. Immune cells regulate the inflammatory response and immunization, which inspired various cell therapy using immune-regulatory cells. Conclusively, we emphasize the need to develop gene-modification-based cell therapy as potent future treatment.
\end{abstract}

Keywords Gene engineering $\cdot$ Cell therapy $\cdot$ Gene-modified cell therapy $\cdot$ Immune cell therapy $\cdot$ Stem cell therapy

\section{Introduction}

Cells can naturally sense and response to the environment by their functionality and living-cells have been challenged for disease therapy. Along with development of biological engineering, various attempts on genetical modification for improvement of cell therapy have been made. Longhistorical viral vector-based gene delivery and non-viral vector-based gene transfection have been reported to facilitate cell modification. Although viral vector-based delivery systems have shown high transfection efficacy, they have serious problems including immune responses and insertional mutagenesis such as ectopic chromosomal integration followed by oncogenic reactions. Synthetic materials have been developed with successful results in gene therapy for various diseases. Though non-viral vectors showed less

Yong-Hee Kim

yongheekim@hanyang.ac.kr

1 Department of Bioengineering, Hanyang University, Seoul 04763, Republic of Korea

2 Institute for Bioengineering and Biopharmaceutical Research, Hanyang University, Seoul 04763, Republic of Korea

3 BK 21 Plus Future Biopharmaceutical Human Resources Training and Research Team, Hanyang University, Seoul 04763, Republic of Korea transfection efficiency compared to viral vectors, the safety issues with reduced pathogenicity and immunogenicity make non-viral vector more likely enter the clinical trials. Otherwise, recent technology of genome editing, especially CRISPR/Cas9 system enables complicated gene editing. In this review, we describe recent development of cell-therapies based on 'genetically-modified' cells. The contents were separated into two parts including genetically-engineered stem cells such as MSCs and HPSCs, and genetically-modified immune cells such as dendritic cells, macrophages and T cells. Finally, we emphasize the 'needs' of genetic engineering for realization of cell therapy for future medicine.

\section{Gene-modified stem cell therapy}

Stem cells have been gaining attention in regenerative medicine due to their self-renewal and multilineage differentiation. Cell therapy based on stem cells are widely used by introducing stem cells into tissues to treat diseases by gene therapy. Most stem cell therapies are based on hematopoietic stem cell and these tissue specific stem cells have now held a place in the cure for numerous diseases. Mesenchymal stem cells are also the most favored cell type in clinical studies due to its immunomodulatory properties. The clinical trials exploit improved vector systems to successfully delivery 
therapeutic genes. Ex vivo cell therapies has been of great interest as they are patients or normal donor oriented. Stem, progenitor or differentiated cells obtained from patients are expanded ex vivo by genetic modification and administered back into patients (Fig. 1).

\section{HSC gene therapy}

Hematopoietic stem cell gene therapy (HSCs) have been the main target for ex vivo gene therapy thanks to the long clinical experience with HSC transplantation leading to highly integrated protocols (Naldini 2011). HSCs have the potential of self-maintaining multipotent to supply corrected gene progeny for hematopoietic lineage failure. The self-renewing nature of HSCs must be stably introduced into the cells either by vector mediated delivery or in situ gene editing (Thomas et al. 2003). The choice of gene delivery is dependent on the type of vectors used and integrating vectors derived from retroviruses [early generation vectors based on gamma-retroviruses ( $\gamma$-RVs)] remain a preferred choice (Braun et al. 2014; Hacein-Bey-Abina et al. 2008; Stein et al. 2010). However, they also highlight the limitations and risks as they have limited ability to transfer genes and low transient expression of corrected hematopoietic cells in vivo. The development of lentiviral vectors with improved efficacy and safety has been of great interest for ex vivo gene therapy. Several clinical trials using lenti-viral vector systems has been incorporated into severe inherited diseases of the immune systems such as Wiskott-Aldrich syndrome (WAS) (Abina et al. 2015; Aiuti et al. 2013) and X-linked severe combined immune-deficiency (SCID-X1) (Hacein-Bey-Abina et al. 2014) and $\beta$-thalassemia (Cavazzana-Calvo et al. 2010) and neurodegenerative disorders (Biffi et al. 2013; Cartier et al. 2009) (Table 1). Studies have focused on better vector development and better HSC processing methods but also focused on target gene editing to improve diseases such as disruption of the gene encoding a protein (Bcl11a) that repress expression of fetal globin for $\beta$-thalassemia (Wilber et al. 2010). Efforts have also been made for the treatment of $\beta$-thalassemia using siRNA by knocking down $\alpha$-globin mRNA (Voon et al. 2008), zinc finger transcription factor Krüppel-like factor 1 (KLF1, also known as the erythroid Krüppel-like factor, EKLF) (Norton et al. 2017) or overexpression of its private chaperone, AHSP (Nasimuzzaman et al. 2010). As for the treatment of WAS

\section{Ex vivo gene therapy}

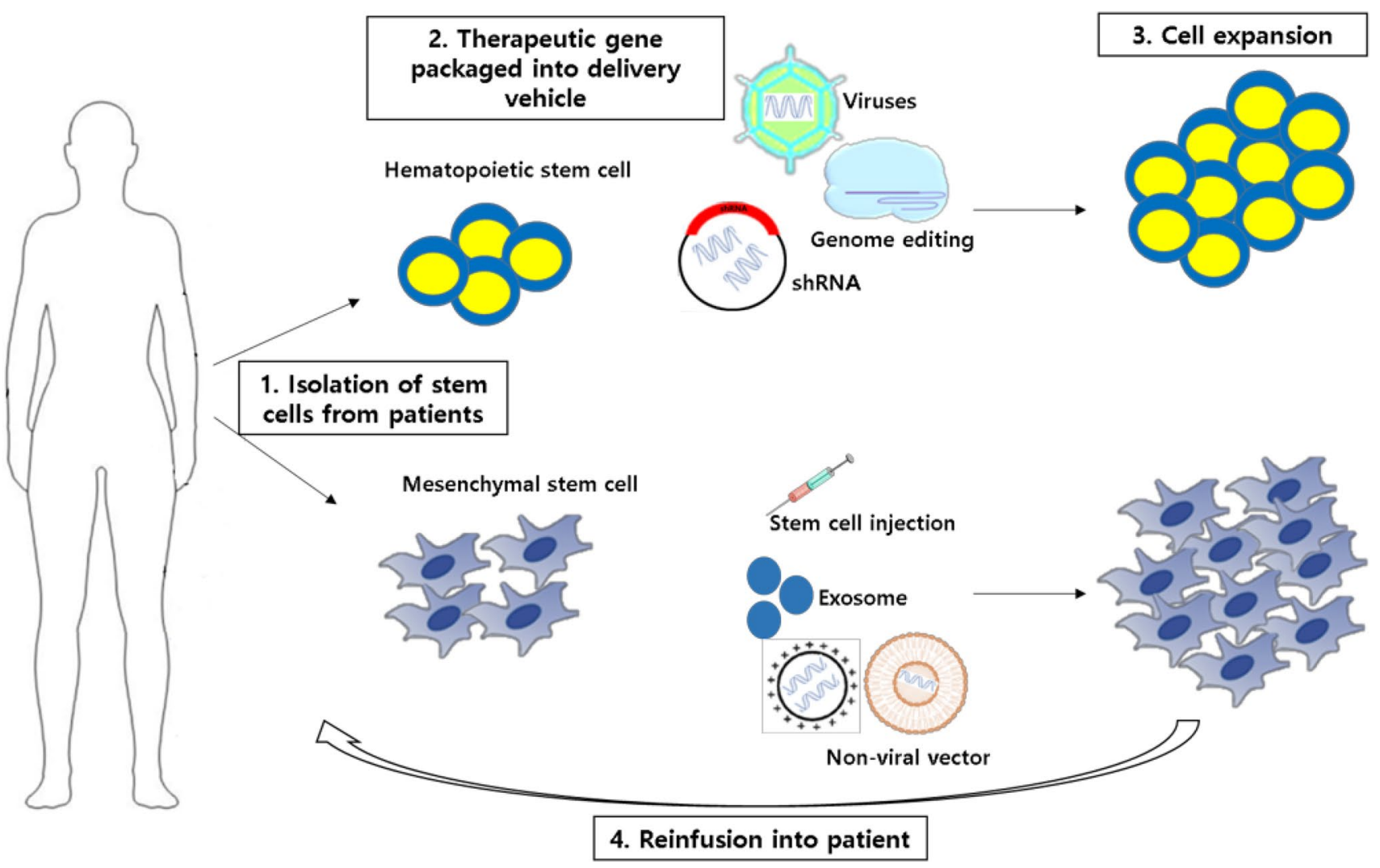

Fig. 1 Ex vivo stem cell gene therapy 
Table 1 Stem cell gene therapy

\begin{tabular}{|c|c|c|c|c|}
\hline Disease & Gene vector & Target cell & Target gene & Refs \\
\hline $\begin{array}{l}\text { HSC gene therapy } \\
\text { WAS }\end{array}$ & $\begin{array}{l}\text { Lentivirus } \\
\text { CRISPR/Cas9 }\end{array}$ & Multi lineage & Was specific gene & $\begin{array}{l}\text { Aiuti et al. (2013); Boztug et al. } \\
\quad(2010) \\
\text { Wang et al. (2015) }\end{array}$ \\
\hline X-linked SCID & $\gamma$ retrovirus & $\begin{array}{l}\text { Lymphocyte } \\
\text { Myeloid }\end{array}$ & IL2RG & Hacein-Bey-Abina et al. (2014) \\
\hline$\beta$ Thalassaemia & $\begin{array}{l}\text { Lentivirus } \\
\text { Lentivirus of shRNA }\end{array}$ & Erythrocyte & $\begin{array}{l}\text { Bcl11a } \\
\text { HMGA2 } \\
\text { KLF1 }\end{array}$ & $\begin{array}{l}\text { Roosjen et al. (2014); Sankaran } \\
\text { et al. (2008) } \\
\text { Zhao et al. (2017) } \\
\text { Amaya et al. (2013); Borg et al. } \\
\text { (2012) }\end{array}$ \\
\hline ALD & Lentivirus & Tissue macrophage and microglia & $\mathrm{ABCD} 1$ & Cartier et al. (2009) \\
\hline MLD & Lentivirus & Tissue macrophage and microglia & ARSA & Biffi et al. (2013) \\
\hline $\begin{array}{l}\text { MSC gene therapy } \\
\text { GVHD }\end{array}$ & $\begin{array}{l}\text { Stem cell injection } \\
\text { Non-viral }\end{array}$ & $\begin{array}{l}\text { MSC, monocyte } \\
\text { T-cell }\end{array}$ & $\begin{array}{l}\text { TGF } \beta \text { CCR } 4, \text { CCR } 8 \\
\text { Let7a }\end{array}$ & $\begin{array}{l}\text { Lim et al. (2017) } \\
\text { Yu et al. (2017) }\end{array}$ \\
\hline Myocardial infarction & Exosomes & Cardiac muscle cell & Nrf2 & Mu et al. (2014) \\
\hline Ischemia & Non-viral & MSC & miR-133b & Huang et al. (2017) \\
\hline Bone and cartilage repain & Biomaterial & BMSCs & BMP-2 & Balmayor et al. (2017) \\
\hline
\end{tabular}

$H S C$ hematopoietic stem cell, MSC mesenchymal stem cell, WAS Wiskott-Alrdich syndrome, X-linked SCID X-linked severe combined immunodeficiency, $A L D$ adrenoleukodystrophy, $M L D$ metachromatic leukodystrophy, $B M S C$ bone marrow mesenchymal stem cell

caused by the mutation in the WAS gene, many retroviruses and lentiviruses that target the WAS gene have been researched on however the genome integration showed undesired off targets. Therefore CRISPR mediated genome editing targeting the WAS gene has been studied for treatment of the disease. SCID, an immune disorder characterized by absence of $\mathrm{T}$ and NK cells have been evaluated by correction of IL2RG gene (Schiroli et al. 2016).

HSCs gene therapy is administered by ex vivo gene transfer into hematopoietic progenitors by purifying CD34 surface marker from leukocytes obtained from bone marrow or peripheral blood. Then CD34 purified cells are cultured for approximately 4 days in presence of growth factors and vectors carrying an expression cassette for the corrective gene (Huang et al. 2016). Before administration of the modified cells, patient's progenitor and differentiated cells are depleted in the bone marrow following chemotherapy. The depletion favors the engraftment of ex vivo corrected gene therapy; however, they also cause secondary tumors and infertility (Copelan 2006). To overcome these problems, several HSCs gene therapy have concentrated by lowering the chemotherapy dosage that are used for HSC transplantation, but they are yet to be determined. Lenti-viral HSCs gene therapy shows high level of hematopoiesis with the corrected genes in most patients and has been no report of adverse events related to lenti-viral gene therapy. Apart from lenti-viral therapy, genome editing by use of CRISPR system shows a great promise for hematopoietic stem cell therapy as more researchers are focusing on improved gene delivery system with efficient gene targeting (Mandal et al. 2014).

\section{MSC gene therapy}

Mesenchymal stem cell (MSC) gene therapy have been widely used in clinical trials due to their heterogenetic properties (Bianco 2014). MSC are classified as postnatal, self-renewing multipotent stem cells that are capable of multilineage differentiation. They are also defined by their spindle shaped morphology, adhering capability in vitro and unique cluster expression during cell differentiation (Wei et al. 2013). Stromal MSCs are defined differently from classic MSC as they are classified from various tissues and shows the properties of fibroblastic markers and when transplanted modulate the host immune system. Due to their safety regarding the short existence, anti-inflammatory properties and homing to damage sites they are widely used for allogenic cell transplantations and clinical studies (Wang et al. 2016). For the past few years, the number of registered clinical trials of MSC gene therapy has increased but the distribution of clinical pipeline is still a major hurdle to overcome. The pleiotropic properties of MSCs provides a broad range for their potential in regeneration of organ tissues, immune related disorders and neurodegenerative diseases (Table 1) and moreover translational studies have proved their attractiveness for clinical use (Glenn and Whartenby 2014). By the end of 2016, there were over 500 clinical studies related to MSC therapy, the main clinical indications being autoimmune diseases and bone cartilage (http://clinicaltrials.gov/).

Immune suppression properties of MSC have important roles in suppressing activated T-cells and their host disease (GVHD), to overcome the serious consequence of GVHD 
MSC have been used in clinical studies due to their immunosuppressive properties. Several phase II clinical studies have shown lower transplant related mortality and higher survival rates when treated together with MSCs. Children suffering from stage III-IV GVHD received MSC and about $42 \%$ of the children survived for a medium of 611 days leading to approval of Prochymal MSC for severe pediatric GVHD in Canada and New Zealand. Apart from clinical studies, diverse researches has been carried out using gene targeting such as down-regulation of TGF-beta expression, inhibition of infiltration of immune cells via down-regulation of CCR4 and CCR8 on monocytes (Lim et al. 2017), microRNA based strategy by knock-down of let-7a to improve MSC immunotherapy (Yu et al. 2017). Apart from immunosuppressive properties, MSCs have been widely used for myocardial infarction, ischemia stroke, osteoarthritis and liver diseases (Buzhor et al. 2014). In myocardial infarction, allogeneic MSC transplants have shown improved ventricular ejection fraction and also the use of exosomes derived from MSCs have been widely used (Gonzalez-King et al. 2017). Various gene therapies have been researched on such as the peptide modified MSC using miR-133b for treatment of cerebral ischemia (Huang et al. 2017) also micelles were used for siRNA transfection into mesenchymal stem cells (Raisin et al. 2017). Bone marrow derived MSCs are widely used for bone and cartilage repair and in osteoarthritic patient's intraarticular injection of MSC resulted in strong improvement of cartilage coverage (Jo et al. 2014) and modified mRNA for BMP-2 to induce osteogenic pathways in MSCs (Balmayor et al. 2017). Due to the advantage of the mesenchymal stem cells, stem cell therapy can be broadened to diverse diseases.

\section{Gene-modified immune cell therapy}

Immune cells are related to various disease pathologies such as inflammatory diseases, cancer, transplantation rejection (Grivennikov et al. 2010; Ross 1999). Due to major role of immune regulation, there are many types of gene-modified immune cell therapy with two main stream of dendritic cell vaccine and CAR-T cell for cancer therapy (Fig. 2).

\section{Gene modified-dendritic cell (DC) for improved tumor vaccination}

DCs are professional antigen presenting cells which presents the phagocytosed and processed antigens to $\mathrm{T}$ cells via MHC and co-stimulatory factors (CD80, CD86). Antigen-presented naïve $\mathrm{T}$ cells expand and matured to $\mathrm{CD} 4+$, $\mathrm{CD} 8+$ effector $\mathrm{T}$ cells to attack, re-act to antigenic cells, especially for cancer. Due to its major role of antigenpresentation, DCs as natural adjuvant, DC-based cancer antigen vaccination has been studied for decades (Lesterhuis et al. 2011; Murphy et al. 1996; Nestle et al. 1998; Romano et al. 2011; Timmerman et al. 2002; Yu et al. 2001). Although with its antigen presenting and clonal $\mathrm{T}$ cell stimulating character, there have been hurdles of DCvaccination; (1) enhancement of antigenic immunity and (2) breaking of immunosuppression by tumor microenvironment; and combinatory gene delivery for improvement of DC-tumor vaccination have been studied. Based on the immunosuppression mechanism in the dendritic cells by SOCS1 gene, lentiviral SOCS1 siRNA delivery reduced immunosuppressive effect in DC and improved antigenic response for $\mathrm{T}$ cell education (Shen et al. 2004). In consistency with SOCS1, siRNA targeting A20, the 'attenuator of antigen presentation' enhanced co-stimulatory factor such as CD80, CD86 and cytokine expression in DCs which overcomes regulatory T-cell-mediated immune suppression (Song et al. 2008). With discovery of PD-L1 and PD-1 interaction (Freeman et al. 2000) in tumor immune suppression, Hobo et al. delivered PD-L1, L2 ligand-targeting siRNA via electroporation to DCs. PD-L1,2 knock downDCs shows reduced interaction with PD-1 on patientderived $\mathrm{T}$ cells and enhanced antigen-specific T cell stimulation with proliferation, consequently boost DC-mediated vaccine effects (Hobo et al. 2010). With liposomal system, Akita et al. delivered siRNA for SOCS1 and improved the vaccinating effect of DCs for tumor vaccination in mice. R8-GALA peptide modified liposome shows better endosomal escape and gene knock down efficiency (Akita et al. 2010) and YSK12-C4 based YSK12-MEND shows dramatic gene delivery efficiency $(\sim 1.5 \mathrm{nM} \mathrm{Km})$ which facilitates DC-gene silencing for lymphoma vaccination compared (Warashina et al. 2016). Spermine-dextran, a kind of cationic polymer-mediated gp100-melanoma antigen delivery showed anti-melanoma effect and CCR7 coexpression improved lymph node migration of transfected dendritic cells in vivo (Chen et al. 2013). Other than that, STAT3 siRNA and R837; immune modifier; containing PLGA nanoparticle improved the maturation and antigen presentation ability of DCs for OVA-cancer therapy (Heo and Lim 2014). Recently direct antigen expressing mRNA delivery also programmed DCs to present antigens for $\mathrm{T}$ cells. Liposome-mediated antigenic mRNA delivery processed MHC II-antigen presentation and induced cancer vaccination effect (Kranz et al. 2016). DC biology have shown heterogeneity in tissue and organ (Geissmann et al. 2010). Recent studies shows different antigen presenting capacity between tissue resident DCs and monocytederived DCs in muscle (Langlet et al. 2012) and tumor (Laoui et al. 2016) which suggest needs-for study on different function, optimization of type-dependent dendritic cell vaccination for future DC vaccine-mediated cancer therapy (Table 2). 

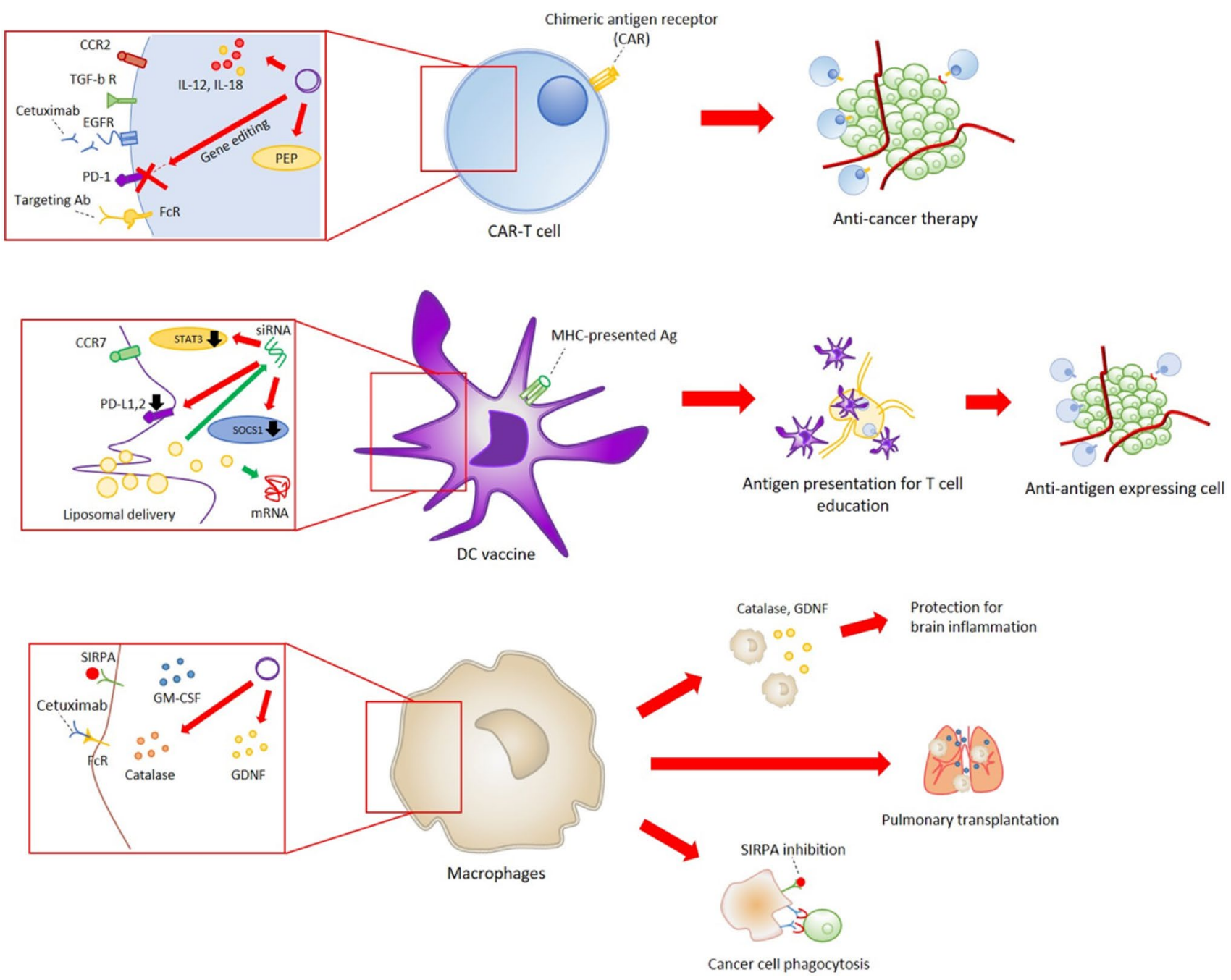

Fig. 2 Gene-modified immune cell therapy

Table 2 Gene-modified DC vaccines

\begin{tabular}{|c|c|c|c|c|}
\hline & Gene vector & Target gene & Target gene function & Refs \\
\hline \multirow[t]{8}{*}{ DC vaccination } & Lentivirus & SOCS1 & Immune suppressor & Shen et al. (2004) \\
\hline & Lentivirus & $\mathrm{A} 20$ & $\begin{array}{l}\text { Attenuator of antigen } \\
\text { presentation }\end{array}$ & Song et al. (2008) \\
\hline & R8-GALA-Lipo & SOCS1 & Immune suppressor & \multirow{3}{*}{$\begin{array}{l}\text { Akita et al. (2010); Warashina et al. (2016); } \\
\text { Geissmann et al. (2010) }\end{array}$} \\
\hline & YSK12-MEND-Lipo & SOCS1 & Antigen expression & \\
\hline & Liposome & Antigenic mRNA & & \\
\hline & Electroporation & PD-L1,2 & Immune suppression & Roosjen et al. (2014); Sankaran et al. (2008) \\
\hline & Spermine-dextran & CCR7 & Lymph organ homing & Chen et al. (2013) \\
\hline & PLGA nanoparticle & STAT3 & DC maturation & Biffi et al. (2013) \\
\hline
\end{tabular}

\section{Gene modification for improved chimeric antigen receptor T cells (CAR-T cells)}

Other than DC vaccines, are proper for antigen-specific effector $\mathrm{T}$ cell expansion and long term tumor immunizations, negative selection in $\mathrm{T}$ cell development against endogenous antigen harden the efficient therapy of self-antigen based DC vaccine (Palucka and Banchereau 2012). Based on the interactions of T cell's CD3, C28 receptors with DC's peptide-loaded MHC II, 
chimeric antigen receptor (CAR) expression-mediated $\mathrm{T}$ cell modification have shown efficient tumor regressions (Kershaw et al. 2006, 2013; Lamers et al. 2006; Park et al. 2007). Mostly well-known CAR-T cell is CD19-targeted one which recognize the CD19 on B cell lymphoma and destroyed them successfully in clinical trial (Brentjens et al. 2013; Davila et al. 2014; Lee et al. 2015). Other than CD19-targeted one, CAR-T cells on chronic leukemias and Her2-solid tumors have been studied (Ahmed et al. 2015; Kalos et al. 2011; Lynn et al. 2015; O'Hear et al. 2015). However, (1) tumor microenvironment-immune suppression and (2) T cell exhaustion, (3) targeting problem requires additional genetic modifications for CAR-T cell improvement. To overcome PD-1 and PD-L1 immunosuppression, extracellular domain of PD-1 was fused to intracellular costimulatory domain which activated $\mathrm{T}$ cells (Prosser et al. 2012; Ren et al. 2017; Schumann et al. 2015) removed PD-1 receptor from $T$ cell genomic DNA by CRISPR/Cas 9 system. The expression of dominant negative receptor form of TGF-beta enhanced immune activation state of $\mathrm{T}$ cells (Foster et al. 2008). Based on glucose-metabolic competition between cancer cell and $\mathrm{T}$ cell, genetically engineered $\mathrm{T}$ cells with increased phosphoenolpyruvate (PEP) expression showed enhanced effector function (Ho et al. 2015). Pro-inflammatory cytokine, IL-12, IL-18 expressing, 'Armed' T cells shows higher anti-tumor effect by stimulating both adaptive and innate immune systems (Boice et al. 2016; Zhang et al. 2015). To eliminate and control transferred-T cell efficiently, extracellular domain of EGFR was expressed on CAR-T cells responsive them to EGFR-antibody such as cetuximab (Wang et al. 2011). Adapter-CAR T cells are advanced form of targeting such as Fc receptor-expression for antibody-decoration (Kudo et al. 2014) and specific ligand binding domain-modification for ligand binding (Ma et al. 2016). With chemotactic migration of CCR 2 , additional CCR2 expression enhanced tumor accumulation and antitumor effect (Moon et al. 2011). Conclusively CAR-T cell modification is still unmet need with great potential for sophisticated cancer therapy (Table 3).

\section{Gene-modified and armed macrophages}

With disease-homing and accumulation character, macrophages are professional phagocytes and immune effectors (Geissmann et al. 2010). As previously described, macrophage accumulation and polarization induce the inflammatory state of disease area such as myocardiac infarction (Swirski et al. 2009) and atherosclerosis (Robbins et al. 2013), adipose tissue (Amano et al. 2014) and tumor (Franklin et al. 2014). Tumor educated-macrophages (tumor associated macrophage; TAM) polarized to M2-like macrophages suppressing inflammatory response and $\mathrm{T}$ cell activations for tumor raise and TAM-depletion mediated anti-cancers are very important issues (Mantovani et al. 2002). Due to effector functions, macrophages have been applied for human disease therapy in clinical trials, mostly shows no therapeutic effects (Knoller et al. 2005; Lammertse et al. 2012; Lee et al. 2016). For improved macrophage-therapy and its clinical success, there have been researches of gene-modified macrophage based therapy. For hereditary pulmonary alveolar proteinosis (herPAP), a disease induced by GM-CSF receptor mutation, Happle et al. (2014) and Suzuki et al. (2014) transplanted pulmonary with GM-CSF expressing macrophage (wild type). The transplanted macrophages differentiated to functional alveolar macrophages reduces proteinosis and enhanced the lung function for lasting 9 months. As previously mentioned tumor infiltrating monocytes and macrophages are a potential target for tumor therapy and Giulia Escobar et al. modified hematopoietic cells to express interferon alpha since their differentiation by using TIE2 promoter based lentiviral vector. Due to tumor infiltrating characteristic of TIE2-expressing monocytes, enhanced interferon-alpha response in tumor and reduced tumor growth was observed which suggest new-tumor immunotherapy (Escobar et al. 2014). With liposomal systems, Haney et al. (2011, 2013) and Zhao et al. (2014) delivered
Table 3 Gene-modified CAR-T cells

\begin{tabular}{llll}
\hline & Target gene & Target gene function & Refs \\
\hline CAR T cell & PD-1 & Immune suppressor & $\begin{array}{l}\text { Schumann et al. (2015) } \\
\text { Ren et al. (2017) }\end{array}$ \\
$\begin{array}{l}\text { Negative form of TGF- } \\
\text { beta receptor }\end{array}$ & Immune suppressor & Foster et al. (2008) \\
PEP & Glucose metabolism & Ho et al. (2015) \\
IL-12 & Immune activation & Boice et al. (2016); \\
IL-18 & & Zhang et al. (2015) \\
EGFR & Cetuximab-binding for apoptotic induction & Wang et al. (2011) \\
Fc receptor & Targeting antibody binding & Kudo et al. (2014) \\
Ligand binding domain & Targeting ligand binding & Ma et al. (2016) \\
CCR2 & Chemotactic migration for tumor targeting & Moon et al. (2011) \\
\hline
\end{tabular}


Table 4 Gene-modified and armed macrophages

\begin{tabular}{lllll}
\hline & Gene vector & Target gene & Target gene function & Refs \\
\hline Macrophage therapy & - & GM-CSF & Macrophage differentiation & Happle et al. (2014) \\
& & & Suzuki et al. (2014) \\
& TIE2-lentivirus & Interferon alpha & Anti-tumor immune response & Escobar et al. (2014) \\
& Catalase & Anti-inflammation, neuronal protection & Haney et al. (2011, \\
& GDNF & & 2013); Zhao et al. \\
& & & Phagocytic signaling & Alvey et al. (2017) \\
\hline
\end{tabular}

catalase and GDNF gene-expressing pDNA into macrophages and injected them intravenously. The macrophages were accumulated in brain and extracellular vesicles released from delivered-macrophages were delivered to neurons by protruding microtubules which reduces inflammation and neuronal destructions, consequently propose the therapy for Parkinson's disease. Other than gene-transfection, antibody and drug-loaded nanoparticle modified macrophages are also promising topic. Anselmo et al. (2015) and Klyachko et al. (2017) engineered the Raw264.7 cells with non-phagocytic microparticle, 'polymeric backpacks' for anti-inflammatory drug delivery in brain and inflamed lung, skin. Recent paper of macrophage therapy introduces the antibody-blocking of SIRP-alpha inhibited CD47 interaction of macrophages on cancer cells which improves phagocytic uptake and removal of cancer. With cetuximab- and anti-SIRP-alpha-antibody modification of macrophages suppresses EGFR-lung tumor growth in mice (Alvey et al. 2017) (Table 4).

\section{Conclusion}

Due to the natural character of the cells, they have been applied for therapy, genetic modification and engineering. They also have a potential for improvement of cell functions. Temporal gene silencing and expression by siRNA and pDNA has been the most valuable approaches and CRISPR/Cas9-mediated gene editing is a promising tool for future cell-engineering.

Acknowledgements This work was partially supported by grants from the National Research Foundation of Korea (2015R1A2A1A09003019), and Bio \& Medical Technology Development Program (NRF 2017M3A9F5029655), the Brain Korea 21 plus program (22A20130011095), and the Korean Health Technology R\&D project through the Ministry of Health and Welfare (HI17C0888).

\section{Compliance with ethical standards}

Conflict of interest All authors (S.B.Yong, J.Y.Chung, Y.S.Song, and Y-H.Kim) declare no conflict of interest.
Open Access This article is distributed under the terms of the Creative Commons Attribution 4.0 International License (http://creativecommons.org/licenses/by/4.0/), which permits use, duplication, adaptation, distribution and reproduction in any medium or format, as long as you give appropriate credit to the original author(s) and the source, provide a link to the Creative Commons license and indicate if changes were made.

\section{References}

Abina SH-B, Gaspar HB, Blondeau J, Caccavelli L, Charrier S, Buckland K, Picard C, Six E, Himoudi N, Gilmour K (2015) Outcomes following gene therapy in patients with severe Wiskott-Aldrich syndrome. Jama 313:1550-1563

Ahmed N, Brawley VS, Hegde M, Robertson C, Ghazi A, Gerken C, Liu E, Dakhova O, Ashoori A, Corder A (2015) Human epidermal growth factor receptor 2 (HER2)-specific chimeric antigen receptor-modified $\mathrm{T}$ cells for the immunotherapy of HER2-positive sarcoma. J Clin Oncol 33:1688-1696

Aiuti A, Biasco L, Scaramuzza S, Ferrua F, Cicalese MP, Baricordi C, Dionisio F, Calabria A, Giannelli S, Castiello MC (2013) Lentiviral hematopoietic stem cell gene therapy in patients with WiskottAldrich syndrome. Science 341:1233151

Akita H, Kogure K, Moriguchi R, Nakamura Y, Higashi T, Nakamura T, Serada S, Fujimoto M, Naka T, Futaki S (2010) Nanoparticles for ex vivo siRNA delivery to dendritic cells for cancer vaccines: programmed endosomal escape and dissociation. J Control Release 143:311-317

Alvey CM, Spinler KR, Irianto J, Pfeifer CR, Hayes B, Xia Y, Cho S, Dingal PD, Hsu J, Smith L (2017) SIRPA-inhibited, marrowderived macrophages engorge, accumulate, and differentiate in antibody-targeted regression of solid tumors. Curr Biol 27:20652077 e2066

Amano SU, Cohen JL, Vangala P, Tencerova M, Nicoloro SM, Yawe JC, Shen Y, Czech MP, Aouadi M (2014) Local proliferation of macrophages contributes to obesity-associated adipose tissue inflammation. Cell Metab 19:162-171

Amaya M, Desai M, Gnanapragasam MN, Wang SZ, Zu Zhu S, Williams DC, Ginder GD (2013) Mi2 $\beta$-mediated silencing of the fetal $\gamma$-globin gene in adult erythroid cells. Blood 121:3493-3501

Anselmo AC, Gilbert JB, Kumar S, Gupta V, Cohen RE, Rubner MF, Mitragotri S (2015) Monocyte-mediated delivery of polymeric backpacks to inflamed tissues: a generalized strategy to deliver drugs to treat inflammation. J Control Release 199:29-36

Balmayor ER, Geiger JP, Koch C, Aneja MK, van Griensven M, Rudolph C, Plank C (2017) Modified mRNA for BMP-2 in combination with biomaterials serves as a transcript-activated matrix 
for effectively inducing osteogenic pathways in stem cells. Stem Cells Dev 26:25-34

Bianco P (2014) "Mesenchymal” stem cells. Annu Rev Cell Dev Biol 30:677-704

Biffi A, Montini E, Lorioli L, Cesani M, Fumagalli F, Plati T, Baldoli C, Martino S, Calabria A, Canale S (2013) Lentiviral hematopoietic stem cell gene therapy benefits metachromatic leukodystrophy. Science 341:1233158

Boice M, Salloum D, Mourcin F, Sanghvi V, Amin R, Oricchio E, Jiang M, Mottok A, Denis-Lagache N, Ciriello G (2016) Loss of the HVEM tumor suppressor in lymphoma and restoration by modified CAR-T cells. Cell 167:405-418. e413

Borg J, Phylactides M, Bartsakoulia M, Tafrali C, Lederer C, Felice AE, Papachatzopoulou A, Kourakli A, Stavrou EF, Christou S (2012) KLF10 gene expression is associated with high fetal hemoglobin levels and with response to hydroxyurea treatment in $\beta$-hemoglobinopathy patients. Pharmacogenomics 13:1487-1500

Boztug K, Schmidt M, Schwarzer A, Banerjee PP, Díez IA, Dewey RA, Böhm M, Nowrouzi A, Ball CR, Glimm H (2010) Stem-cell gene therapy for the Wiskott-Aldrich syndrome. N Engl J Med 363:1918-1927

Braun CJ, Boztug K, Paruzynski A, Witzel M, Schwarzer A, Rothe M, Modlich U, Beier R, Göhring G, Steinemann D (2014) Gene therapy for Wiskott-Aldrich syndrome-long-term efficacy and genotoxicity. Sci Transl Med 6:227ra233-227ra233

Brentjens RJ, Davila ML, Riviere I, Park J, Wang X, Cowell LG, Bartido S, Stefanski J, Taylor C, Olszewska M (2013). CD19-targeted $\mathrm{T}$ cells rapidly induce molecular remissions in adults with chemotherapy-refractory acute lymphoblastic leukemia. Sci Transl Med 5:177ra138-177ra138

Buzhor E, Leshansky L, Blumenthal J, Barash H, Warshawsky D, Mazor Y, Shtrichman R (2014). Cell-based therapy approaches: the hope for incurable diseases. Regener Med 9, 649-672

Cartier N, Hacein-Bey-Abina S, Bartholomae CC, Veres G, Schmidt M, Kutschera I, Vidaud M, Abel U, Dal-Cortivo L, Caccavelli L (2009). Hematopoietic stem cell gene therapy with a lentiviral vector in X-linked adrenoleukodystrophy. Science 326:818-823

Cavazzana-Calvo M, Payen E, Negre O, Wang G, Hehir K, Fusil F, Down J, Denaro M, Brady T, Westerman K (2010) Transfusion independence and HMGA2 activation after gene therapy of human [bgr]-thalassaemia. Nature 467:318-322

Chen Y-Z, Ruan G-X, Yao X-L, Li L-M, Hu Y, Tabata Y, Gao J-Q (2013) Co-transfection gene delivery of dendritic cells induced effective lymph node targeting and anti-tumor vaccination. Pharm Res 30:1502-1512

Copelan EA (2006) Hematopoietic stem-cell transplantation. N Engl J Med 354:1813-1826

Davila ML, Riviere I, Wang X, Bartido S, Park J, Curran K, Chung SS, Stefanski J, Borquez-Ojeda O, Olszewska M (2014) Efficacy and toxicity management of 19-28z CAR T cell therapy in B cell acute lymphoblastic leukemia. Sci Transl Med 6:224ra225-224ra225

Escobar G, Moi D, Ranghetti A, Ozkal-Baydin P, Squadrito ML, Kajaste-Rudnitski A, Bondanza A, Gentner B, De Palma M, Mazzieri R (2014) Genetic engineering of hematopoiesis for targeted IFN- $\alpha$ delivery inhibits breast cancer progression. Sci Transl Med 6:217ra213-217ra213

Foster AE, Dotti G, Lu A, Khalil M, Brenner MK, Heslop HE, Rooney CM, Bollard CM (2008). Antitumor activity of EBV-specific T lymphocytes transduced with a dominant negative TGF- $\beta$ receptor. J Immunother (Hagerstown, Md: 1997) 31:500

Franklin RA, Liao W, Sarkar A, Kim MV, Bivona MR, Liu K, Pamer EG, Li MO (2014) The cellular and molecular origin of tumorassociated macrophages. Science 344:921-925

Freeman GJ, Long AJ, Iwai Y, Bourque K, Chernova T, Nishimura H, Fitz LJ, Malenkovich N, Okazaki T, Byrne MC (2000) Engagement of the PD-1 immunoinhibitory receptor by a novel B7 family member leads to negative regulation of lymphocyte activation. J Exp Med 192:1027-1034

Geissmann F, Manz MG, Jung S, Sieweke MH, Merad M, Ley K (2010) Development of monocytes, macrophages, and dendritic cells. Science 327:656-661

Glenn JD, Whartenby KA (2014). Mesenchymal stem cells: emerging mechanisms of immunomodulation and therapy. World J Stem Cells 6:526

Gonzalez-King H, García NA, Ontoria-Oviedo I, Ciria M, Montero JA, Sepúlveda P (2017). Hypoxia inducible factor- $1 \alpha$ potentiates jagged 1-mediated angiogenesis by mesenchymal stem cell-derived exosomes. Stem Cells 35:1747-1759

Grivennikov SI, Greten FR, Karin M (2010) Immunity, inflammation, and cancer. Cell 140:883-899

Hacein-Bey-Abina S, Garrigue A, Wang GP, Soulier J, Lim A, Morillon E, Clappier E, Caccavelli L, Delabesse E, Beldjord K (2008). Insertional oncogenesis in 4 patients after retrovirus-mediated gene therapy of SCID-X1. J Clin Invest 118:3132

Hacein-Bey-Abina S, Pai S-Y, Gaspar HB, Armant M, Berry CC, Blanche S, Bleesing J, Blondeau J, De Boer H, Buckland KF (2014) A modified $\gamma$-retrovirus vector for X-linked severe combined immunodeficiency. N Engl J Med 371:1407-1417

Haney MJ, Zhao Y, Li S, Higginbotham SM, Booth SL, Han H-Y, Vetro JA, Mosley RL, Kabanov AV, Gendelman HE (2011) Cell-mediated transfer of catalase nanoparticles from macrophages to brain endothelial, glial and neuronal cells. Nanomedicine 6:1215-1230

Haney MJ, Zhao Y, Harrison EB, Mahajan V, Ahmed S, He Z, Suresh P, Hingtgen SD, Klyachko NL, Mosley RL (2013) Specific transfection of inflamed brain by macrophages: a new therapeutic strategy for neurodegenerative diseases. PLoS ONE 8:e61852

Happle C, Lachmann N, Škuljec J, Wetzke M, Ackermann M, Brennig S, Mucci A, Jirmo AC, Groos S, Mirenska A (2014) Pulmonary transplantation of macrophage progenitors as effective and longlasting therapy for hereditary pulmonary alveolar proteinosis. Sci Transl Med 6:250ra113-250ra113

Heo MB, Lim YT (2014) Programmed nanoparticles for combined immunomodulation, antigen presentation and tracking of immunotherapeutic cells. Biomaterials 35:590-600

Ho P-C, Bihuniak JD, Macintyre AN, Staron M, Liu X, Amezquita R, Tsui Y-C, Cui G, Micevic G, Perales JC (2015) Phosphoenolpyruvate is a metabolic checkpoint of anti-tumor T cell responses. Cell $162: 1217-1228$

Hobo W, Maas F, Adisty N, de Witte T, Schaap N, van der Voort R, Dolstra H (2010) siRNA silencing of PD-L1 and PD-L2 on dendritic cells augments expansion and function of minor histocompatibility antigen-specific CD8+ T cells. Blood 116:4501-4511

Huang X, Lee M-R, Cooper S, Hangoc G, Hong K-S, Chung H-M, Broxmeyer HE (2016) Activation of OCT4 enhances ex vivo expansion of human cord blood hematopoietic stem and progenitor cells by regulating HOXB4 expression. Leukemia 30:144-153

Huang B, Jiang X-C, Zhang T-Y, Hu Y-L, Tabata Y, Chen Z, Pluchino S, Gao J-Q (2017) Peptide modified mesenchymal stem cells as targeting delivery system transfected with miR-133b for the treatment of cerebral ischemia. Int J Pharm 531:90-100

Jo CH, Lee YG, Shin WH, Kim H, Chai JW, Jeong EC, Kim JE, Shim H, Shin JS, Shin IS (2014) Intra-articular injection of mesenchymal stem cells for the treatment of osteoarthritis of the knee: a proof-of-concept clinical trial. Stem Cells 32:1254-1266

Kalos M, Levine BL, Porter DL, Katz S, Grupp SA, Bagg A, June CH (2011) T cells with chimeric antigen receptors have potent antitumor effects and can establish memory in patients with advanced leukemia. Sci Transl Med 3:95ra73-95ra73

Kershaw MH, Westwood JA, Parker LL, Wang G, Eshhar Z, Mavroukakis SA, White DE, Wunderlich JR, Canevari S, RogersFreezer L (2006) A phase I study on adoptive immunotherapy 
using gene-modified $\mathrm{T}$ cells for ovarian cancer. Clin Cancer Res 12:6106-6115

Kershaw MH, Westwood JA, Darcy PK (2013) Gene-engineered T cells for cancer therapy. Nat Rev Cancer 13:525-541

Klyachko NL, Polak R, Haney MJ, Zhao Y, Neto RJG, Hill MC, Kabanov AV, Cohen RE, Rubner MF, Batrakova EV (2017) Macrophages with cellular backpacks for targeted drug delivery to the brain. Biomaterials 140:79-87

Knoller N, Auerbach G, Fulga V, Zelig G, Attias J, Bakimer R, Marder JB, Yoles E, Belkin M, Schwartz M (2005) Clinical experience using incubated autologous macrophages as a treatment for complete spinal cord injury: phase I study results. J Neurosurg Spine 3:173-181

Kranz LM, Diken M, Haas H, Kreiter S, Loquai C, Reuter KC, Meng M, Fritz D, Vascotto F, Hefesha H (2016). Systemic RNA delivery to dendritic cells exploits antiviral defence for cancer immunotherapy. Nature 534:396-401

Kudo K, Imai C, Lorenzini P, Kamiya T, Kono K, Davidoff AM, Chng WJ, Campana D (2014) T lymphocytes expressing a CD16 signaling receptor exert antibody-dependent cancer cell killing. Cancer Res 74:93-103

Lamers CH, Sleijfer S, Vulto AG, Kruit WH, Kliffen M, Debets R, Gratama JW, Stoter G, Oosterwijk E (2006) Treatment of metastatic renal cell carcinoma with autologous T-lymphocytes genetically retargeted against carbonic anhydrase IX: first clinical experience. J Clin Oncol 24:e20-e22

Lammertse D, Jones L, Charlifue S, Kirshblum S, Apple D, Ragnarsson K, Falci S, Heary R, Choudhri T, Jenkins A (2012) Autologous incubated macrophage therapy in acute, complete spinal cord injury: results of the phase 2 randomized controlled multicenter trial. Spinal Cord 50:661-671

Langlet C, Tamoutounour S, Henri S, Luche H, Ardouin L, Grégoire C, Malissen B, Guilliams M (2012) CD64 expression distinguishes monocyte-derived and conventional dendritic cells and reveals their distinct role during intramuscular immunization. J Immunol 188:1751-1760

Laoui D, Keirsse J, Morias Y, Van Overmeire E, Geeraerts X, Elkrim Y, Kiss M, Bolli E, Lahmar Q, Sichien D (2016) The tumour microenvironment harbours ontogenically distinct dendritic cell populations with opposing effects on tumour immunity. Nat Commun 7:13720

Lee DW, Kochenderfer JN, Stetler-Stevenson M, Cui YK, Delbrook C, Feldman SA, Fry TJ, Orentas R, Sabatino M, Shah NN (2015) $\mathrm{T}$ cells expressing CD19 chimeric antigen receptors for acute lymphoblastic leukaemia in children and young adults: a phase 1 dose-escalation trial. Lancet 385:517-528

Lee S, Kivimäe S, Dolor A, Szoka FC (2016) Macrophage-based cell therapies: The long and winding road. J Control Release 240:527-540

Lesterhuis WJ, de Vries IJM, Schreibelt G, Lambeck AJ, Aarntzen EH, Jacobs JF, Scharenborg NM, van de Rakt MW, de Boer AJ, Croockewit S (2011). Route of administration modulates the induction of dendritic cell vaccine-induced antigen-specific $\mathrm{T}$ cells in advanced melanoma patients. Clin Cancer Res 17:5725-5735

Lim J-Y, Ryu D-B, Lee S-E, Park G, Min C-K (2017) Mesenchymal stem cells (MSCs) attenuate cutaneous sclerodermatous graft-versus-host disease (Scl-GVHD) through inhibition of immune cell infiltration in a mouse model. J Invest Dermatol 137:1895-1904

Lynn RC, Poussin M, Kalota A, Feng Y, Low PS, Dimitrov DS, Powell DJ (2015) Targeting of folate receptor $\beta$ on acute myeloid leukemia blasts with chimeric antigen receptor-expressing $\mathrm{T}$ cells. Blood 125:3466-3476

Ma JS, Kim JY, Kazane SA, Choi S-h, Yun HY, Kim MS, Rodgers DT, Pugh HM, Singer O, Sun SB (2016). Versatile strategy for controlling the specificity and activity of engineered $\mathrm{T}$ cells. Proc Natl Acad Sci USA 113:E450-E458
Mandal PK, Ferreira LM, Collins R, Meissner TB, Boutwell CL, Friesen M, Vrbanac V, Garrison BS, Stortchevoi A, Bryder D (2014) Efficient ablation of genes in human hematopoietic stem and effector cells using CRISPR/Cas9. Cell Stem Cell 15:643-652

Mantovani A, Sozzani S, Locati M, Allavena P, Sica A (2002) Macrophage polarization: tumor-associated macrophages as a paradigm for polarized M2 mononuclear phagocytes. Trends Immunol 23:549-555

Moon EK, Carpenito C, Sun J, Wang L-CS, Kapoor V, Predina J, Powell DJ, Riley JL, June CH, Albelda SM (2011) Expression of a functional CCR2 receptor enhances tumor localization and tumor eradication by retargeted human $\mathrm{T}$ cells expressing a mesothelin-specific chimeric antibody receptor. Clin Cancer Res 17:4719-4730

Mu J, Zhuang X, Wang Q, Jiang H, Deng ZB, Wang B, Zhang L, Kakar S, Jun Y, Miller D (2014). Interspecies communication between plant and mouse gut host cells through edible plant derived exosome-like nanoparticles. Mol Nutr Food Res 58, $1561-1573$

Murphy G, Tjoa B, Ragde H, Kenny G, Boynton A (1996) Phase I clinical trial: T-cell therapy for prostate cancer using autologous dendritic cells pulsed with HLA-A0201-specific peptides from prostate-specific membrane antigen. Prostate 29:371-380

Naldini L (2011) Ex vivo gene transfer and correction for cell-based therapies. Nat Rev Genet 12:301-315

Nasimuzzaman M, Khandros E, Wang X, Kong Y, Zhao H, Weiss D, Rivella S, Weiss MJ, Persons DA (2010) Analysis of alpha hemoglobin stabilizing protein overexpression in murine $\beta$-thalassemia. Am J Hematol 85:820-822

Nestle FO, Alijagic S, Gilliet M, Sun Y, Grabbe S, Dummer R, Burg G, Schadendorf D (1998) Vaccination of melanoma patients with peptide-or tumorlysate-pulsed dendritic cells. Nat Med 4:328-332

Norton LJ, Funnell AP, Burdach J, Wienert B, Kurita R, Nakamura Y, Philipsen S, Pearson RC, Quinlan KG, Crossley M (2017). KLF1 directly activates expression of the novel fetal globin repressor ZBTB7A/LRF in erythroid cells. Blood Adv 1:685-692

O’Hear C, Heiber JF, Schubert I, Fey G, Geiger TL (2015). Anti-CD33 chimeric antigen receptor targeting of acute myeloid leukemia. Haematologica 100:336-344

Palucka K, Banchereau J (2012) Cancer immunotherapy via dendritic cells. Nat Rev Cancer 12:265-277

Park JR, DiGiusto DL, Slovak M, Wright C, Naranjo A, Wagner J, Meechoovet HB, Bautista C, Chang W-C, Ostberg JR (2007) Adoptive transfer of chimeric antigen receptor re-directed cytolytic T lymphocyte clones in patients with neuroblastoma. Mol Ther 15:825-833

Prosser ME, Brown CE, Shami AF, Forman SJ, Jensen MC (2012). Tumor PD-L1 co-stimulates primary human CD8+ cytotoxic T cells modified to express a PD1: CD28 chimeric receptor. Mol Immunol 51:263-272

Raisin S, Morille M, Bony C, Noël D, Devoisselle J-M, Belamie E (2017). Tripartite polyionic complex (PIC) micelles as non-viral vectors for mesenchymal stem cell siRNA transfection. Biomater Sci 5:1910-1921

Ren J, Liu X, Fang C, Jiang S, June CH, Zhao Y (2017) Multiplex genome editing to generate universal CAR T cells resistant to PD1 inhibition. Clin Cancer Res 23:2255-2266

Robbins CS, Hilgendorf I, Weber GF, Theurl I, Iwamoto Y, Figueiredo J-L, Gorbatov R, Sukhova GK, Gerhardt LM, Smyth D (2013) Local proliferation dominates lesional macrophage accumulation in atherosclerosis. Nat Med 19:1166-1172

Romano E, Rossi M, Ratzinger G, de Cos M-A, Chung DJ, Panageas KS, Wolchock JD, Houghton AN, Chapman PB, Heller G (2011) Peptide-loaded Langerhans cells, despite increased IL15 secretion and T-cell activation in vitro, elicit antitumor T-cell responses 
comparable to peptide-loaded monocyte-derived dendritic cells in vivo. Clin Cancer Res 17:1984-1997

Roosjen M, McColl B, Kao B, Gearing LJ, Blewitt ME, Vadolas J (2014) Transcriptional regulators Myb and BCL11A interplay with DNA methyltransferase 1 in developmental silencing of embryonic and fetal $\beta$-like globin genes. FASEB J 28:1610-1620

Ross R (1999) Atherosclerosis_an inflammatory disease. N Engl J Med 340:115-126

Sankaran VG, Menne TF, Xu J, Akie TE, Lettre G, Van Handel B, Mikkola HK, Hirschhorn JN, Cantor AB, Orkin SH (2008) Human fetal hemoglobin expression is regulated by the developmental stage-specific repressor BCL11A. Science 322:1839-1842

Schiroli G, Genovese P, Capo V, Castiello MC, Albano L, Holmes MC, Villa A, Sitia G, Lombardo A, Naldini L (2016). 42. Correction of SCID-X1 by targeted genome editing of hematopoietic stem/progenitor cells (HSPC) in the mouse model. Mol Ther 24:S18-S19

Schumann K, Lin S, Boyer E, Simeonov DR, Subramaniam M, Gate RE, Haliburton GE, Chun JY, Bluestone JA, Doudna JA (2015). Generation of knock-in primary human T cells using Cas9 ribonucleoproteins. Proc Natl Acad Sci USA 112:10437-10442

Shen L, Evel-Kabler K, Strube R, Chen S-Y (2004) Silencing of SOCS1 enhances antigen presentation by dendritic cells and antigen-specific anti-tumor immunity. Nat Biotechnol 22:1546-1553

Song X-T, Kabler KE, Shen L, Rollins L, Huang XF, Chen S-Y (2008) A20 is an antigen presentation attenuator, and its inhibition overcomes regulatory $\mathrm{T}$ cell-mediated suppression. Nat Med $14: 258-265$

Stein S, Ott MG, Schultze-Strasser S, Jauch A, Burwinkel B, Kinner A, Schmidt M, Krämer A, Schwäble J, Glimm H (2010) Genomic instability and myelodysplasia with monosomy 7 consequent to EVI1 activation after gene therapy for chronic granulomatous disease. Nat Med 16:198-204

Suzuki T, Arumugam P, Sakagami T, Lachmann N, Chalk C, Sallese A, Abe S, Trapnell C, Carey B, Moritz T (2014) Pulmonary macrophage transplantation therapy. Nature 514:450-454

Swirski FK, Nahrendorf M, Etzrodt M, Wildgruber M, Cortez-Retamozo V, Panizzi P, Figueiredo J-L, Kohler RH, Chudnovskiy A, Waterman P (2009) Identification of splenic reservoir monocytes and their deployment to inflammatory sites. Science 325:612-616

Thomas CE, Ehrhardt A, Kay MA (2003) Progress and problems with the use of viral vectors for gene therapy. Nat Rev Genet 4:346-358

Timmerman JM, Czerwinski DK, Davis TA, Hsu FJ, Benike C, Hao ZM, Taidi B, Rajapaksa R, Caspar CB, Okada CY (2002) Idiotype-pulsed dendritic cell vaccination for B-cell lymphoma: clinical and immune responses in 35 patients. Blood 99:1517-1526

Voon HPJ, Wardan H, Vadolas J (2008) siRNA-mediated reduction of $\alpha$-globin results in phenotypic improvements in $\beta$-thalassemic cells. Haematologica 93:1238-1242
Wang X, Chang W-C, Wong CW, Colcher D, Sherman M, Ostberg JR, Forman SJ, Riddell SR, Jensen MC (2011) A transgene-encoded cell surface polypeptide for selection, in vivo tracking, and ablation of engineered cells. Blood 118:1255-1263

Wang X, Wang Y, Wu X, Wang J, Wang Y, Qiu Z, Chang T, Huang H, Lin R-J, Yee J-K (2015) Unbiased detection of off-target cleavage by CRISPR-Cas9 and TALENs using integrase-defective lentiviral vectors. Nat Biotechnol 33:175-178

Wang L-T, Ting C-H, Yen M-L, Liu K-J, Sytwu H-K, Wu KK, Yen BL (2016) Human mesenchymal stem cells (MSCs) for treatment towards immune-and inflammation-mediated diseases: review of current clinical trials. J Biomed Sci 23:76

Warashina S, Nakamura T, Sato Y, Fujiwara Y, Hyodo M, Hatakeyama $\mathrm{H}$, Harashima H (2016) A lipid nanoparticle for the efficient delivery of siRNA to dendritic cells. J Control Release 225:183-191

Wei X, Yang X, Han Z-p, Qu F-f, Shao L, Shi Y-f (2013) Mesenchymal stem cells: a new trend for cell therapy. Acta Pharmacol Sin 34:747-754

Wilber A, Tschulena U, Hargrove PW, Kim Y-S, Persons DA, Barbas $\mathrm{CF}$, Nienhuis AW (2010) A zinc-finger transcriptional activator designed to interact with the $\gamma$-globin gene promoters enhances fetal hemoglobin production in primary human adult erythroblasts. Blood 115:3033-3041

Yu JS, Wheeler CJ, Zeltzer PM, Ying H, Finger DN, Lee PK, Yong WH, Incardona F, Thompson RC, Riedinger MS (2001) Vaccination of malignant glioma patients with peptide-pulsed dendritic cells elicits systemic cytotoxicity and intracranial T-cell infiltration. Cancer Res 61:842-847

Yu Y, Liao L, Shao B, Su X, Shuai Y, Wang H, Shang F, Zhou Z, Yang D, Jin Y (2017) Knockdown of MicroRNA Let-7a improves the functionality of bone marrow-derived mesenchymal stem cells in immunotherapy. Mol Ther 25:480-493

Zhang L, Morgan RA, Beane JD, Zheng Z, Dudley ME, Kassim SH, Nahvi AV, Ngo LT, Sherry RM, Phan GQ (2015). Tumor-infiltrating lymphocytes genetically engineered with an inducible gene encoding interleukin-12 for the immunotherapy of metastatic melanoma. Clin Cancer Res 21:2278-2288

Zhao Y, Haney MJ, Gupta R, Bohnsack JP, He Z, Kabanov AV, Batrakova EV (2014). GDNF-transfected macrophages produce potent neuroprotective effects in Parkinson's disease mouse model. PLoS ONE 9, e106867

Zhao HF, Abraham A, Kim Y-S, Wang Y-D, Pestina T, Zhan J, Humphries K, Nienhuis AW, Persons DA (2017) Lentiviral transfer of $\gamma$-globin with fusion gene NUP98-HOXA10HD expands hematopoietic stem cells and ameliorates murine $\beta$-thalassemia. Mol Ther 25:593-605 